\title{
CONTRIBUTIONS TO THE JAPANESE ASCIDIAN FAUNA XXVIII. - ASCIDIANS FROM THE AMAMI ISLANDS-
}

\section{$\operatorname{AUTHOR(S):~}$}

Nishikawa, Teruaki; Tokioka, Takasi

\section{CITATION:}

Nishikawa, Teruaki ... [et al]. CONTRIBUTIONS TO THE JAPANESE ASCIDIAN FAUNA XXVIII. ASCIDIANS FROM THE AMAMI ISLANDS-. PUBLICATIONS OF THE SETO MARINE BIOLOGICAL LABORATORY 1976, 22(6): 379-402

ISSUE DATE:

1976-02-28

URL:

http://hdl.handle.net/2433/175911

RIGHT: 


\title{
CONTRIBUTIONS TO THE JAPANESE ASGIDIAN FAUNA XXVII. ASCIDIANS FROM THE AMAMI ISLANDS.")
}

\author{
Teruaki NiSHIKAWA and Takasi TOKIOKA \\ Seto Marine Biological Laboratory
}

With Text-figures $1-7$

Little has been reported on the ascidian fauna of the Amami Islands lying between the Tokara Islands of Kagosima Prefecture and the Ryukyu Archipelago of Okinawa Prefecture. Now, two small materials of ascidians from the Islands are available at hand. One collection was made by Mr. T. Majima in April to May, 1961 at Ankyaba (安脚場), Amami-osima Island and offered by Dr. D. Miyadi, Professor Emeritus of Kyoto University, to the last author for examination, while the other material was collected by Dr. S. Ohishi during her surverys for parasitic copepods of ascidians in the Islands and submitted to the same author for identification.

A small part of these materials, two species of simple ascidians and the same number of species of compound ascidians, was studied by Mr. Makoto Matsumoto in the last class at the Zoological Institute of Kyoto University, but most of simple ascidians were examined by the first and most of compound ascidians by the last author. These examinations resulted in the identification of the following twentythree species.

Aplousobranchia

1. Polyclinum vasculosum Pizon

2. Amaroucium multiplicatum (Sluiter)

3. Pseudodistoma kanoko Tokioka and Nishikawa

4. Didemnum (Didemnum) moseleyi (Herdman)

5. Didemnum (Didemnum) dorotubu Tokioka

6. Leptoclinides reticulatus (Sluiter)

7. Diplosoma mitsukurii Oka

8. Polycitor proliferus (Oka)

Phlebobranchia

9. Perophora formosana (Oka)

10. Ascidia sydneiensis samea (Oka)

11. Ascidia pacifica Tokioka

1) Contributions from the Seto Marine Biological Laboratory, No. 609.

Publ. Seto Mar. Biol. Lab., XXII (6), 377-402, 1976.

(Article 28) 

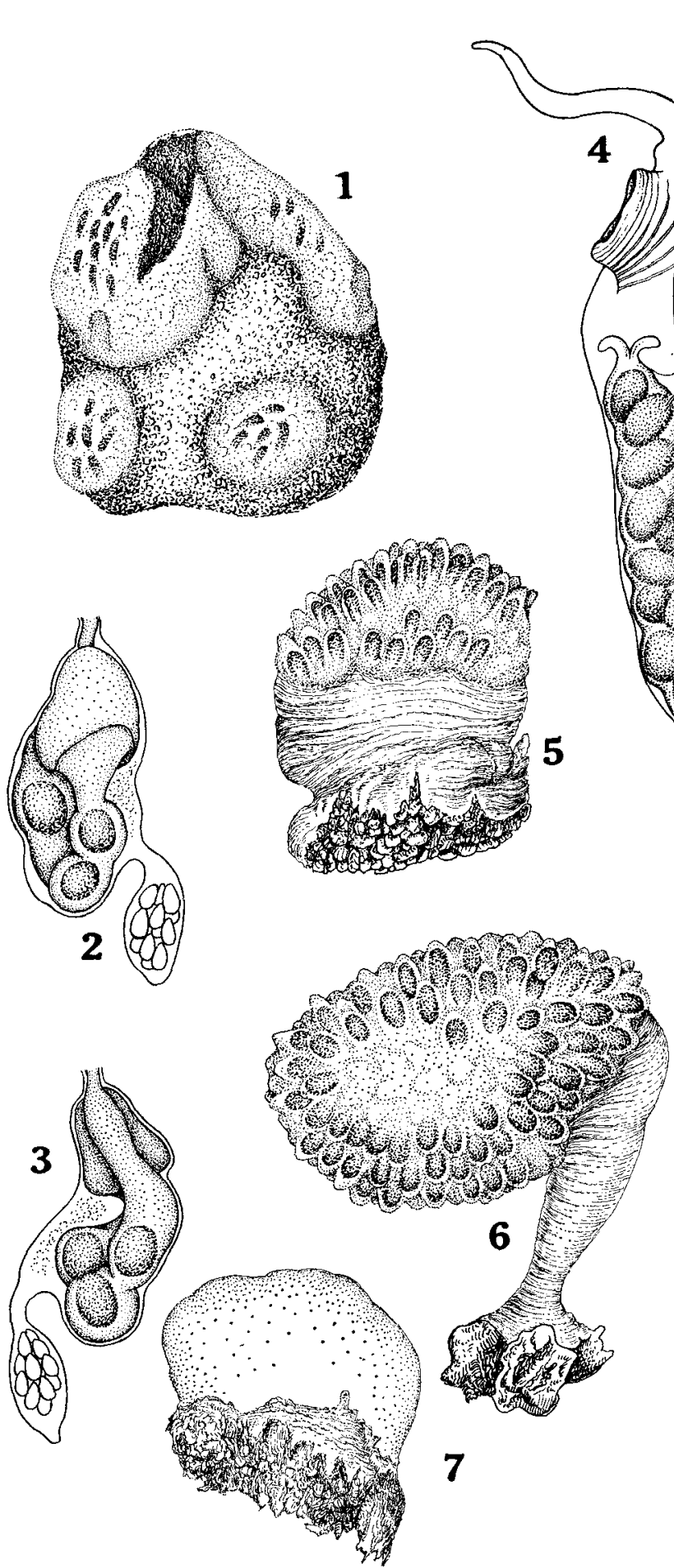

Fig. 1. 1-3: Polyclinum vasculosum Pizon. 1-Colony surface. 2,3-Abdomen. 4: Amaroucium multiplicatum (Sluiter), right side of a zooid. 5-7: Pseudodistoma kanoko Tokioka and Nishikawa, colonies. 7 -In a resting state. 
latter, but without any coecum at the junction, and includes in an examined $8.5 \mathrm{~mm}$ long zooid 23 faecal pellets within it, 15 of them in the distal thoracic portion.

The postabdomen is constricted off distinctly from the abdomen; several ova occupy the left anterior side and up to 60 testicular follicles are clustered in a mass. A larva found in some zooid is $960 \mu$ long and provided with ampullae as follows.

$\begin{array}{lccc} & \text { Anterior area } & \text { Middle part of trunk } & \text { Tail base } \\ \text { Left side } & \text { D. }{ }_{2.3 .3 .4} \mathrm{~V} . & \text { dorsal : }{ }_{0}^{1} \text { ventral : } & 1 \\ \text { Right side } & & & 1\end{array}$

This arrangement seems to conform essentially to that shown by Tokioka (1967, p. 39, fig. 9).

Remarks: Zooids of the present colonies show some differences from those, described by Tokioka, of many colonies from the tropical Pacific, especially in the appearance of thoracic muscles. However, this seems reflecting the difference in the position of the atrial languet, that is considerably variable (see Tokioka 1967, p. 38, lines 8-11). And further, the structure of thoracic musculature might affect the contraction degree and then bring about a larger and extended state of the thorax in less contracted zooids of the present colonies. The body length, up to 8$9 \mathrm{~mm}$, of zooids here described is evidently much larger than that given by Sluiter (1909: $5 \mathrm{~mm}$, with $2 \mathrm{~mm}$ long thorax) or by Tokioka (1967: 4.5-6 mm, with $3 \mathrm{~mm}$ long thorax).

\section{Pseudodistoma kanoko Tokioka and Nishikawa, 1975}

(Fig. 1, 5-7; Fig. 2)

Pseudodistoma kanoko Tokioka and Nishikawa (1975): Publ. Seto Mar. Biol. Lab., 22 (5), pp. 324-26, figs. 1-4.

Three colonies collected at Ankyaba, 3-5 m deep, on May, 30, 1961. One small colony (Fig. 1, 7), $12 \mathrm{~mm}$ in diameter and $12 \mathrm{~mm}$ high, is massive and probably in a resting stage, as the grayish brown colony is quite smooth on the surface and contains deep inside merely regenerating buds which are about $1 \mathrm{~mm}$ long and with the rudimentary thorax. One of the other two is very strange in having a kind of peduncle (Fig. 1, 6), though it is unknown whether or not this is a usual feature. The corona is $17 \mathrm{~mm}$ long, $13 \mathrm{~mm}$ wide, and $10 \mathrm{~mm}$ thick laterally, while the peduncle is $23 \mathrm{~mm}$ in length. The test is brownish and reddish orange zooids are found most densely in a narrow zone along the upper contour (in the text-figure) of the corona, in the range of about $20 \mathrm{~mm}$.

The third colony (Fig. 1, 5) is rather massive again, $14 \mathrm{~mm}$ long, $17 \mathrm{~mm}$ high, and $5 \mathrm{~mm}$ thick laterally. The distal half, about $9 \mathrm{~mm}$ high, forms the corona with the soft gelatinous test, while the basal half assumes a stout peduncle with the much harder test and attaching to the substratum by the proximal end. The test is grayish brown and translucent; zooids are still reddish orange after the preservation for 14 years and found most densely in a narrow apical area of the corona, about $5 \mathrm{~mm}$ 
$\times 16 \mathrm{~mm}$ in extent. Zooids included in this colony are all contracted very strongly in thorax and abdomen, and the postabdomen is bent strongly in every zooid. This is evidently related with the gonadal maturation and the development of larvae inside the nuchal portion of the postabdomen. As seen in Figure 2, the fertilization must be achieved at the site of the ovary in the postabdomen, though it is unknown if this is done by self-fertilization. Anyhow, fertilized eggs develop successively to

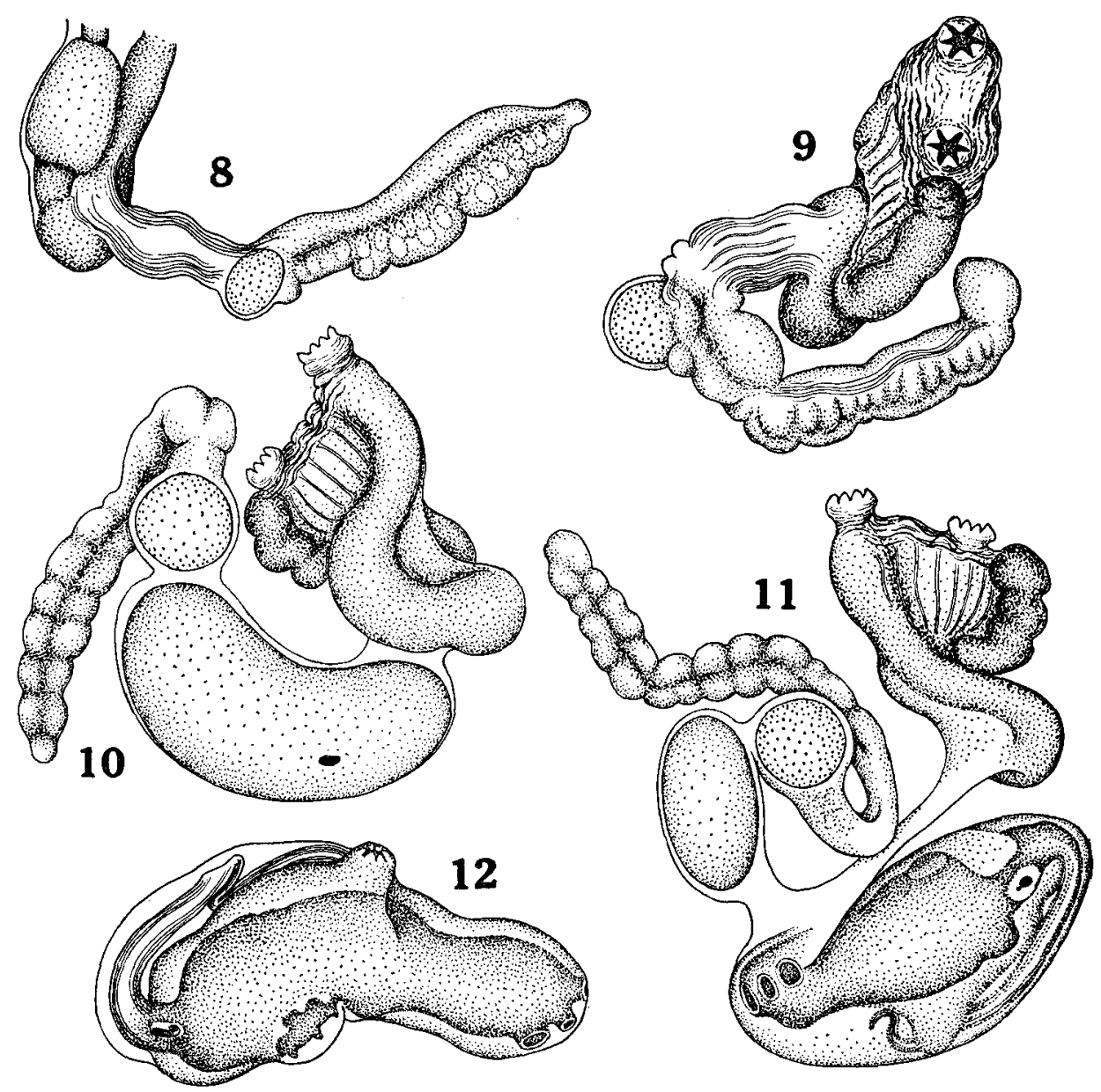

Fig. 2. Pseudodistoma kanoko Tokioka and Nishikawa. 8-11-Development from mature egg to larvea in the nuchal region of postabdomen. 12-Larva.

the embryo (Fig. 2, 10-11) in the elongated nuchal region, and with this the thorax and abdomen become contracted probably, at least partly, by degeneration. The embryo is protruded out from the region (Fig. 2, 11) till it reaches the colony surface when it attains the stage of a completed larva which then might escape from the mother colony through the colony surface by tearing of the superficial layer of the test. No incubatory pouch is formed. The larva is very large, $2.1 \mathrm{~mm}$ long in an 
examined specimen, with 3 disc-shaped attachment-processes arranged lineally and eye-pigments near the posterior end of the trunk; the pigments are arranged anteroposteriorly and the apertures are seemingly 6-lobed already (Fig. 2, 12).

The thorax is about $600 \mu$ in strongly contracted zooids and furnished on each side with about 10 strong longitudinal muscles. The branchial and atrial apertures are clearly 6-lobed. About 8 stigmata in each of 3 rows are fringed distinctly with yellowish pigments. The abdomen is about $900 \mu$ in the same contracted state and the stomach is situated near the middle of the abdomen and with the smooth surface. The postabdomen is up to $2.1 \mathrm{~mm}$ in length and issued from the left side of the abdomen that is somewhat twisted in the contracted state.

\section{Didemnum (Didemnum) moseleyi (Herdman, 1886)}

(Fig. 3, 13-16)

Three small white pieces from the surface of Corella japonica collected at Ankyaba on May 8, 1961. They are $4 \mathrm{~mm} \times 3 \mathrm{~mm}, 6 \mathrm{~mm} \times 3 \mathrm{~mm}$, and $6 \mathrm{~mm} \times 5 \mathrm{~mm}$ in extent and respectively $1 \mathrm{~mm}, 1 \mathrm{~mm}$, and $0.5 \mathrm{~mm}$ in thickness. The largest colony is provided with 2 common cloacal apertures near the centre, each about $0.5 \mathrm{~mm}$ in diameter, and contains about 100 zooids. The smallest colony harbours a small gammarid amphipod.

Spicules are distributed densely and evenly throughout the colony, the superficial spiculeless layer is undefinable. They are rather small, 15 to $33 \mu$, but usually 18 to $21 \mu$ in diameter; rays are usually 6 or 7 on the equatorial plane, 6 rays in larger and 8 in smaller spicules.

The thorax is $300 \mu$ long in a contracted state, the thoracic organ near the postero-ventral corner of the atrial opening contains a spicule, the retractile muscle is $240 \mu$ long. The abdomen is $480 \mu$ in width, testicular follicle 1 and the vas deferens coils several times.

\section{Didemnum (Didemnum) dorotubu Tokioka, 1963}

Didemnum (Didemnum) dorotubu Tokioka (1963): Publ. Seto Mar. Biol. Lab., 11 (1), p. 133. (1967): U.S. Nat. Mus. Bull. 251, pp. 74-75.

The present specific name was newly given to Hypurgon fuscum Oka, 1931. As it had been cleared that H. fuscum is included in Didemnum (Didemnum) and that the specific name "fuscum" is preoccupied in the genus Didemnum, a new name was proposed for the species. This was to be to be done in the paper "Pacific Tunicata of the United States National Museum". After the manuscript of this paper was sent out, the manuscript of another paper "Contributions to Japanese ascidian fauna. XX. The outline of Japanese ascidian fauna as compared with that on the Pacific coasts of North America" was prepared. And in the latter, the species was given in the new name, because it was expected naturally that the former would 

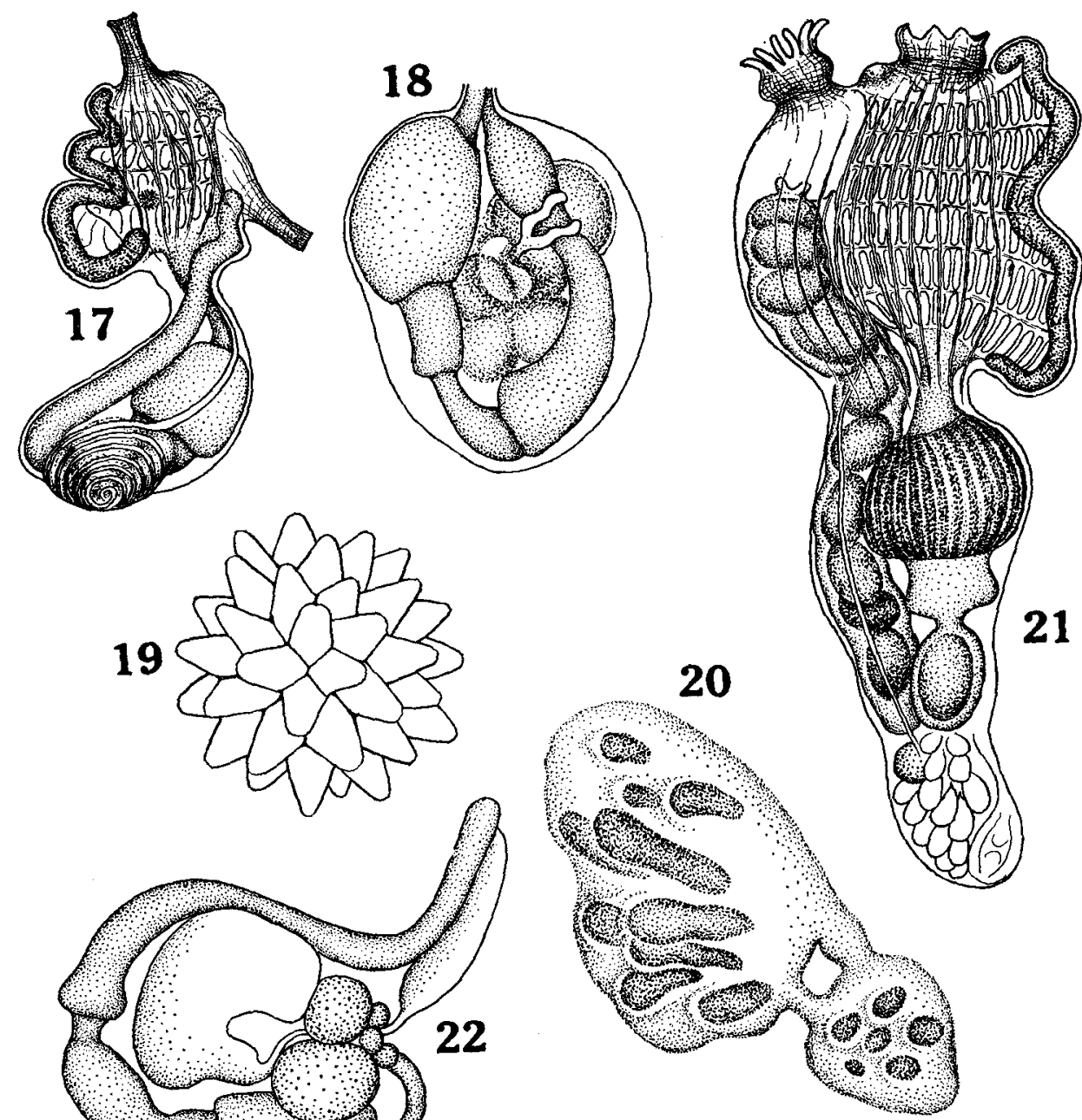

19
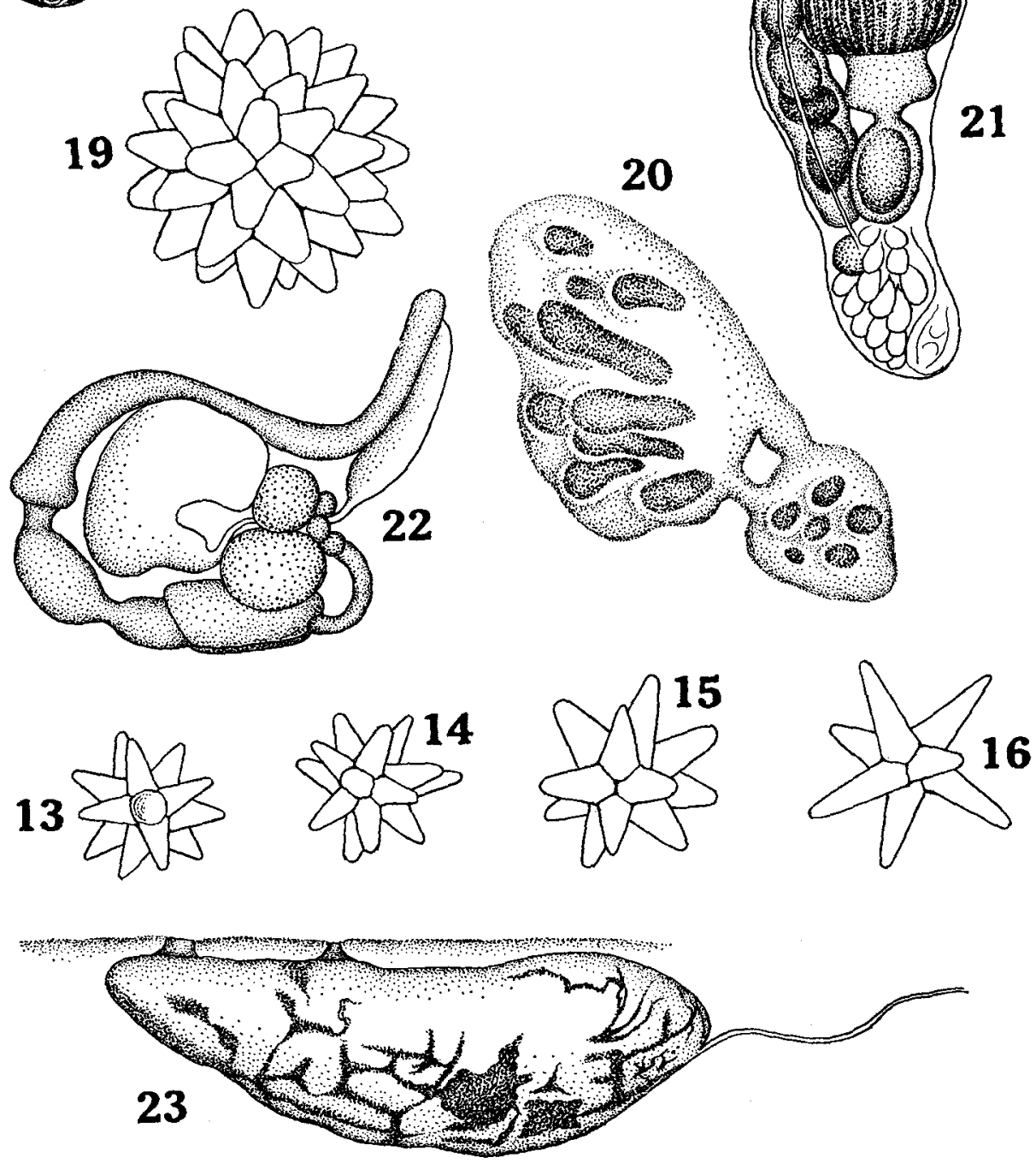
have been published already when the latter was printed. However, this was not the case. The publication of the former was much retarded and then it became clear that the latter would appear earlier than the former. Thus, the name doro$t u b u$ on the list in the latter was given as a new name but without explanations that appeared in the former four years later.

The colonies in the materials consist of three pieces and a small fragment collected at Simoiso, Ankyaba on May 30, 1961; they are respectively $8 \mathrm{~mm} \times 5 \mathrm{~mm}$, $27 \mathrm{~mm} \times 8 \mathrm{~mm}$, and $15 \mathrm{~mm} \times 16 \mathrm{~mm}$ in extent and $1 \mathrm{~mm}$ in thickness. They are all with the typical feature of "Hypurgon" and spicules are very sparse, though a small amount of them are aggregated around the branchial aperture of respective zooids. They are 24 to $33 \mu$, but most frequently about $30 \mu$ in diameter in a worn state and about 9 rays are counted on the equatorial plane. The thoracic organ present, testicular follicle 1 and the vas deferens coiling at least 5 times.

\section{Leptoclinides reticulatus (Sluiter, 1909)}

(Fig. 3, 17-19)

Leptoclinides reticulatus Hastings (1931): Great Barrier Reef Exp., Sci. Rep., 4 (3), p. 92.

Tokioka (1967): U.S. Nat. Mus. Bull. 251, pp. 89-92.

An oval, uniformly pale brown colony, $13 \mathrm{~mm} \times 9 \mathrm{~mm}$ in extent and $1.8 \mathrm{~mm}$ thick, carried on the carapace, $8 \mathrm{~mm}$ in width, of a dromiid crab collected at Ankyaba on June 1, 1961. Four common cloacal apertures are open in the posterior part (as carried on the crab back) of the colony. The test is rather hard in the surface layer, but soft and somewhat sticky in deeper layers. The superficial spiculeless layer is discernible. Spicules are large, 38 to $63 \mu$, but $48 \mu$ on an average in diameter and with 12 to 15 short, stout rays on the equatorial plane. They are arranged above zooids in a single stratum just below the superficial clear layer, but in several layers between zooids. In the inner part of the colony, spicules are distributed very sparsely only along the surface of lacunae. Mean distance between branchial apertures marked by 6 lobules on the surface is $614 \mu$. Zooids are laid nearly parallel to the surface with the dorsal side below and open to the hypozooidal lacuna through the atrial siphon. In the bottom layer, there are embeded embryos.

The thorax is 540 to $600 \mu$ long in a contracted state and the abdomen is $720 \mu$ long at the maximum. The tip of the branchial siphon is usually truncated in zooids taken out of the colony as seen in L. lissus figured by Hastings (1931). About 6 longitudinal muscles on each side of the thorax and a few more than 6 stigmata

Fig. 3. 13-16: Didemnum (Didemnum) moseleyi (Herdman, spicules, $\times 630$. 17-19: Leptoclinides reticulatus (Sluiter). 17-Left side of a zooid. 18-Abdomen, right side. 19-Spicule, $\times 630$. 20-21: Polycitor proliferus (Oka). 20-A colony ( $7 \mathrm{~mm} \times 6 \mathrm{~mm}$ in extent and $3 \mathrm{~mm}$ thick) issuing a smaller bud colony $(3 \mathrm{~mm} \times 2.5 \mathrm{~mm}$ in extent). 21-Zooid, right side. 22-Perophora formosana (Oka), gonad. 23-Botrylloides violaceus Oka, a large zooid opening directly to the exterior by both apertures. 
in each of 4 rows. The anus opens at the postero-dorsal corner; the thoracic organ is generally indiscernible, though a spicule may be found at the corresponding site in some zooids. Tentacles about 8 .

The abdomen is bent, with its right side towards the thorax and the left side facing the lacuna. Three to 4 testicular follicles are seen in the gonads with immature ova, but only 2 in those with a large fully developed egg; the vas deferens coils up to 7 times.

Although the present colony is devoid of the pigment deposit showing a reticulated pattern on the surface, features and structures of zooids and spicules seem to justify the identification with reticulatus.

\section{Diplosoma mitsukurii Oka, 1892}

Three fragments from the surface of Corella japonica collected at Ankyaba on May 8, 1961.

\section{Polycitor proliferus (Oka, 1933)}

(Fig. 3, 20-21)

Polycitor proliferus Tokioka (1953): Ascidians of Sagami Bay, pp. 204-206; pl. 1, fig. 3; pl. 25, figs. $1-8$.

There are 32 colonies in the material collected at Ankyaba, $4 \mathrm{~m}$ deep, on May 30, 1961. The smallest colony is $3 \mathrm{~mm} \times 5 \mathrm{~mm}$ and the largest $10 \mathrm{~mm} \times 13 \mathrm{~mm}$ in extent, the thickness is 2 to $5 \mathrm{~mm}$ throughout the colonies, but most frequently 3 to $4 \mathrm{~mm}$. Numbers of zooids contained are as follows in examined colonies.

$\begin{array}{cc}\text { Colony size } & \text { Number of zooids } \\ (3 \mathrm{~mm} \times 5 \mathrm{~mm}) \times 2.5 \mathrm{~mm} & 12 \\ \text { in extent } & \text { thickness } \\ (3 \mathrm{~mm} \times 6 \mathrm{~mm}) \times 3 \mathrm{~mm} & 10+1 \mathrm{bud} \\ (4 \mathrm{~mm} \times 7 \mathrm{~mm}) \times 2.5 \mathrm{~mm} & 9 \\ (4 \mathrm{~mm} \times 8 \mathrm{~mm}) \times 5 \mathrm{~mm} & 20 \\ (5 \mathrm{~mm} \times 7 \mathrm{~mm}) \times 4 \mathrm{~mm} & 17 \\ (6 \mathrm{~mm} \times 7 \mathrm{~mm}) \times 3 \mathrm{~mm} & 10 \\ (6 \mathrm{~mm} \times 7 \mathrm{~mm}) \times 4 \mathrm{~mm} & 15 \\ (6 \mathrm{~mm} \times 8 \mathrm{~mm}) \times 2 \mathrm{~mm} & 14 \\ (6 \mathrm{~mm} \times 10 \mathrm{~mm}) \times 3.5 \mathrm{~mm} & 16 \\ (6 \mathrm{~mm} \times 11 \mathrm{~mm}) \times 4 \mathrm{~mm} & 22 \\ (6 \mathrm{~mm} \times 14 \mathrm{~mm}) \times 4 \mathrm{~mm} & 30 \\ (6 \mathrm{~mm} \times 14 \mathrm{~mm}) \times 4 \mathrm{~mm} & 30 \\ (7 \mathrm{~mm} \times 8 \mathrm{~mm}) \times 3.5 \mathrm{~mm} & 18 \\ (10 \mathrm{~mm} \times 13 \mathrm{~mm}) \times 2 \mathrm{~mm} & 23\end{array}$

The figures given above seem to show that included zooids are increased with the height of colonies. A stage of colonial proliferation is shown in Fig. 3, 20.

The test is gelatinous, soft, but a little harder than in Amaroucium multiplicatum, 
faintly milky white, and translucent to transparent; zooids are seen through the test. In some colonies whitish spherules are included in some part of the test. The test surface is always free from foreign matters.

Zooids are slightly longer than $3 \mathrm{~mm}$ in a rather extended state; the thorax occupying nearly (but always less than) a half, while the abdomen one-third to nearly a half of the body length, and the postabdomen 50 to $70 \%$ of the abdomen length. The branchial aperture is 6-lobed. The atrial aperture is essentially 6-lobed, too. However, these lobes are more or less subdivided into lobules as seen below.

$\begin{array}{ccc}\text { Dorsal side } & \text { Ventral side } & \text { Total (lobes and lobules) } \\ 8 \text { simple lobules } & 3 \text { large lobes } & 11 \\ 4 \text { simple lobules } & 5 \text { bifid lobes } & 9 \\ 4 \text { simple lobules } & 4 \text { bifid lobes } & 8\end{array}$

Probably first, each lobe of the atrial aperture might become bifid, and then the bifid state might proceed to the completely subdivided state on the dorsal side, while be retained on the ventral side. About a dozen longitudinal muscles on each side of the thorax. Fifteen to 20 stigmata in each of 6 rows. The anus opens at the level of the 3rd transverse vessel. Each vessel is furnished with a developed membrane. Tentacles 12, larger and smaller ones alternating. The incubatory pouch is formed in some zooids at the posterodorsal part on the right side, only a single mature egg was found there in examined zooids. Faecal pellets in the distal thoracic portion of the rectum 4 to 6 .

The stomach is situated with the pyloric end at the middle of the abdomen, a little broader than long, and with 24 to 30 plications on the surface. Both the hindstomach and middle intestine are distinctly defined, the latter is slightly longer than the former. The rectum is constricted off from the middle intestine, but never forming any coecum at this joint. The vas deferens may become swollen prominently in the abdomen in some zooids.

No significant constriction between the postabdomen and abdomen. Eggs are found just behind the middle intestine and on the left side. Testicular follicles up to 25-30 and clustered.

\section{Perophora formosana (Oka, 1931)}

(Fig. 3, 22)

Perophora formosana Tokioka (1953): Ascidians of Sagami Bay, pp. 218-220; pl. 31, figs. 4-5; textfig. 9 on p. 73.

A few zooids were found attached to the peduncle of a colony of Pseudodistoma kanoko. A $2 \mathrm{~mm}$ long (in the mantle body) zooid examined is fully matured as seen from its gonad shown in the text-figure. Transverse muscles in the anterior half of the body are rather diffused, running across the dorso-median line on both the anterior and posterior sides of the atrial aperture, and about 6 when they are count- 
ed at the ventral end. Five stigmatal rows are definable distinctly. The stomach rather elongate.

\section{Ascidia sydniensis samea (Oka, 1935)}

(Fig. 4, 24-25)

Ascidia sydneiensis samea Tokioka (1953): Ascidians of Sagami Bay, p. 226; pl. 34, figs. 6-10; pl. 35, figs. 1-10; pl. 36, figs. 1-10. (1967): U.S. Nat. Mus. Bull. 251, pp. 138-140, fig. 50.

Nishikawa and Tokioka (1975): Publ. Seto Mar. Biol. Lab., 22 (1/4), pp. 220-221, fig. 2.

A small, somewhat damaged specimens collected by Ohishi at Honohosi on July $11,1963,26 \mathrm{~mm}$ long $\times 10 \mathrm{~mm}$ wide, immature. Test surface smooth, but carrying a small amount of sand grains. Mantle musculature typical for the subspecies, the anterior margin of intestinal loop at the level of the anterior edge of atrial aperture.

Transverse vessels about 70 , internal longitudinal vessels about 50 on each side of branchial sac, intermediate papillae absent, about 4 stigmata in a mesh, no plications formed on the wall of sac. Tentacles about 60 , ciliated groove simple, tip of ribs on dorsal lamina slightly projected out from the margin. Stomach rather globular, with about 6 plications on only the left side, axis of second intestinal loop passing across stomach near the middle, anal margin plain.

\section{Ascidia pacifica Tokioka, 1967}

(Fig. 4, 26)

Ascidia pacifica Tokioka (1967): Publ. Seto Mar. Biol. Lab., 14 (5), pp. 399-400, fig. 4.

A small immature specimen, $22 \mathrm{~mm}$ long $\times 20 \mathrm{~mm}$ wide, collected by Ohishi at Honohosi on July 11, 1963. The body is damaged at the terminal branchial siphon inclusive of tentacles and ciliated groove and in the distal half of the atrial siphon that is situated slightly posterior to the middle of the body. The test is gelatinous, thin, transparent, and furnished densely all over the surface with conical papillae, about $10 \mu$ in height.

Mantle musculature just similar to that of $A$. sydneiensis, the anterior margin of intestinal loop reaching anteriorly far beyond the level of atrial siphon.

Transverse vessels about 100, thicker and thinner ones alternating regularly; internal longitudinal vessels about 30 on each side, intermediate papillae absent, about 4 stigmata in a mesh, no plications formed on the sac wall. Stomach elongate and furnished with indistinct plications, axis of second intestinal loop across intestine a little behind the pyloric end of stomach, the basal portion of rectum prominently swollen, anal margin plain.

Remarks: Although the ciliated groove is unknown in the present specimen, the papillated feature on the test surface may be enough to attribute the specimen having the mantle musculature of the "sydeiensis" type to the present species. 


\section{Ascidia aperta Sluiter, 1904}

Ascidia aperta Sluiter (1904): Siboga Exped., Monogr. 56a, pp. 38-39; pl. 2, fig. 4; pl. 6, figs. 1-5. Van Name (1918): U.S. Nat. Mus. Bull. 100, 1 (2), pp. 119-121, figs. 75-76.

Tokioka (1954): Publ. Seto Mar. Biol. Lab., 3 (3), p. 257; pl. 32, figs. 2-8; pl. 33, figs. 1-4. (1967): U.S. Nat. Mus. Bull. 251, pp. 143-145, fig. 53.

A $25 \mathrm{~mm}$ long $\times 14 \mathrm{~mm}$ wide specimen collected by Ohishi at Kasari (笠利) on July 5, 1963. The test is very thin, transparent, gelatinous but tough; the
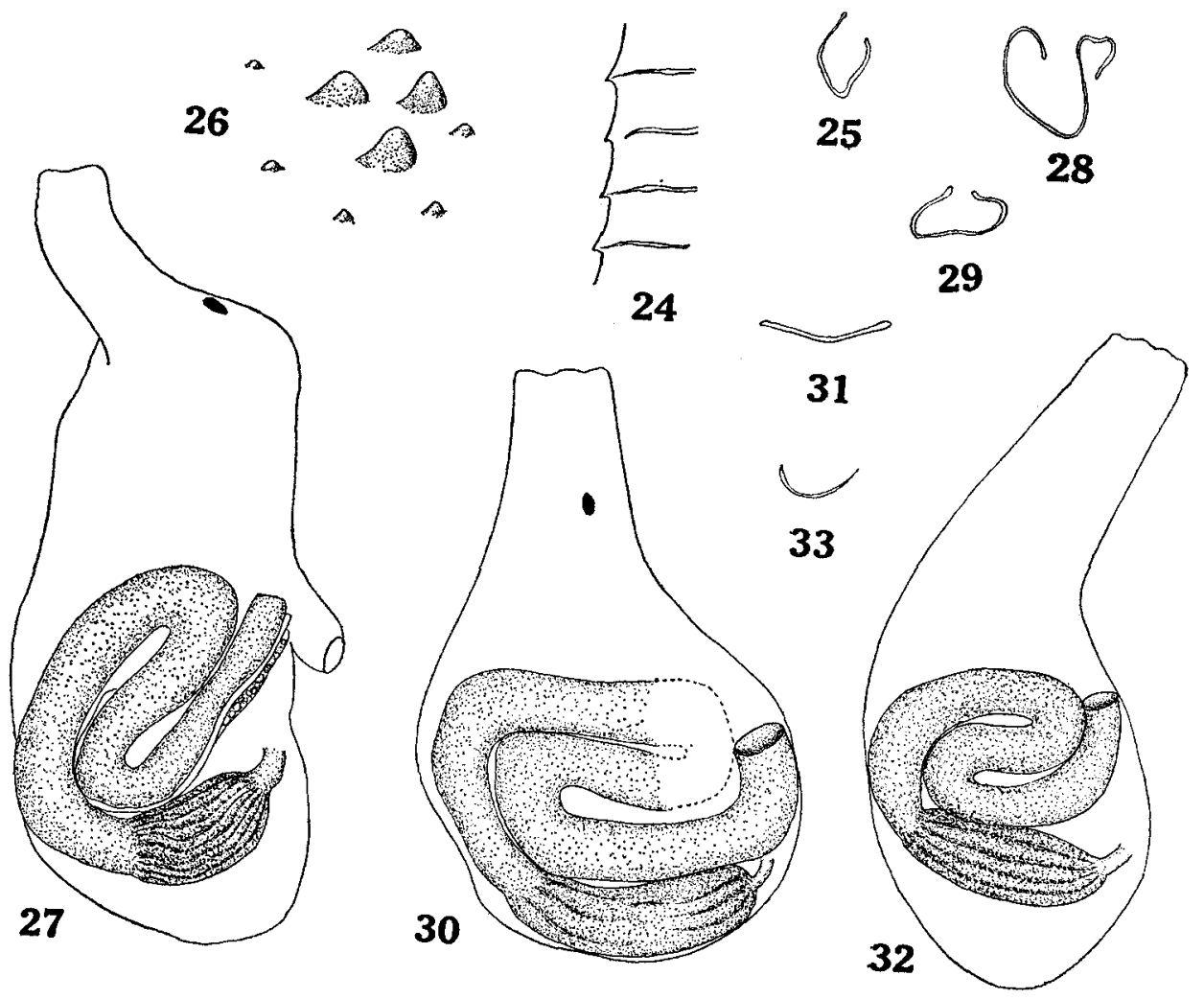

Fig. 4. 24-25: Ascidia sydneiensis samea (Oka). 24-a part of dorsal lamina. 25-ciliated groove. 26: Ascidia pacifica Tokioka, conical prominences on test surface. 27-29: Ascidia alpha Tokioka. 27-mantle body of $31 \mathrm{~mm}$ long $\times 16 \mathrm{~mm}$ wide specimen, left side. 28-ciliated groove of the same specimen. 29 -ciliated groove of $40 \mathrm{~mm}$ long $\times 12 \mathrm{~mm}$ wide specimen. $30-33$ : Ascidia sp. aff. gamma Tokioka. $30-$ mentle body of $18 \mathrm{~mm}$ long $\times 16 \mathrm{~mm}$ wide specimen, left side. 31 -ciliated groove of the same specimen. 32-mantle body of $16 \mathrm{~mm}$ long $\times 12 \mathrm{~mm}$ wide specimen, left side. 33--ciliated groove of the same specimen.

surface is irregularly wrinkled and carrying some sand grains. Branchial aperture terminal and 8-lobed, the atrial near the middle of body and 7-lobed; each lobe with an elongate whitish marking along the axis. The mantle body is furnished rather densely with muscles, mainly transverse, on the whole right side. The anterior margin of the visceral mass never reaches anteriorly over the level of the atrial aperture, the first intestinal loop is opened extremely widely. 
Prebranchial zone not papillated; tentacles about 60, larger and smaller ones alternating; ciliated groove U-shaped, open widely, and with both ends inrolled; 55-56 transverse and 26(left)-30 (right) internal lontitudinal vessels on respective sides of branchial sac, about 5 stigmata in a mesh, intermediate papillae present, no plications definable on the sac wall; dorsal lamina very high and serrated.

Stomach elongate, with 3 rather distinct plications on the right and 3 indistinct ones on the left side; second intestinal loop very shallow, its exis passing across oesophagus, anal margin cut into 8 (?) lobes. A number of pale yellow egg-like bodies, up to $160 \mu$ in diameter, are found attached to the inner wall of the stomach, though their nature is unknown (ref. Tokioka 1954, p. 259). Ovary fully matured; oviduct full of eggs, the aperture cup-shaped and with the frilled margin.

Remarks: Tokioka (1967) reports from the Marshall Islands some specimens that are nearly devoid of muscles on the right side of the mantle body. Most specimens described by Sluiter (1904), Van Name (1918) and Tokioka (1954) are seemingly situated between the specimens from the Marshall Islands and the present specimen as to the development of the musculature.

The stomach is rather globular in the specimens from the Tokara Islands (Tokioka 1954), but somewhat elongate in the specimens from the Marshall Islands (Tokioka 1967, fig. 53) as in the present specimen, and the specimens described by Sluiter (1904) and Van Name (1918) seem to bear the stomach in intermediate states.

The edge of the dorsal lamina may be serrated as in the present specimen and those from the Tokara (Tokioka 1954) and Marshall Islands (Tokioka 1967), plain throughout as in the specimens of Siboga Expedition (Sluiter 1904), or in an intermediate state as in the specimens from Philippine waters (Van Name 1918). Only, it is to be noted that the internal longitudinal vessels are much fewer in the present specimen than in those from the Marshall Islands (50 in a $25 \mathrm{~mm}$ long specimen in the latter).

\section{Ascidia alpha Tokioka, 1953}

(Fig. 4, 27-29)

Ascidia alpha Tokioka (1953): Phbl. Seto Mar. Biol. Lab., 3 (1), pp. 10-11, fig. 6. (1954): ibid., 4 (1), pp. 82-83; pl. 6, fig. 11.

Two specimens collected by Ohishi at Honohosi on July 11, 1963. They are somewhat elongated, respectively $40 \mathrm{~mm}$ long $\times 19 \mathrm{~mm}$ wide and $35 \mathrm{~mm}$ long $\times$ $16 \mathrm{~mm}$ wide. Unfortunately, both specimens are damaged, especially heavily in the larger one; therefore the following description bases on the observations on the smaller specimen.

Test thin, gelatinous but tough, colourless and transparent. Branchial aperture terminal and 8 (?)-lobed, the atrial opening on short but distinct siphon situated slightly behind the middle of body. As the musculature covering the whole right side of the mantle body consists of very fine transverse and oblique muscles, 
the mantle is faintly grayish white and nearly transparent. Visceral mass occupying the posterior half of mantle body, with the anterior end of intestinal loop just at the level of atrial siphon. Dorsal ganglion situated near the base of branchial siphon.

About 100 transverse and 40 internal longitudinal vessels on each side of branchial sac, tentacles about 20 exclusive of minute ones in the left half of ring; ciliated groove U-shaped, with both ends turning to the left. The first and second intestinal loops are very deep, the axis of the latter passes across the intestine slightly behind the pyloric end of the stomach which is elongate and furnished with indistinct plications. Anal margin plain. Gonads fully matured, ovary branched over the right side of visceral mass. Two notodelphid copepods found in branchial sac. Remarks: In the larger specimen, the second intestinal loop is open rather widely and the axis passes across the middle of the stomach. Probably, this is a deformation caused by heavy damage. Although much more posterior situation of the atrial siphon is noted in the present specimens, they may safely be identified with alpha as their general structures agree well with those of this species.

14. Ascidia sp. aff. gamma Tokioka, 1954

(Fig. 4, 30-33)

Ascidia gamma Tokioka (1954): Publ. Seto Mar. Biol. Lab., 4 (1), p. 83; pl. 6, figs. 12-15.

Two more or less injured specimens collected by Ohishi at Honohosi on July 11,1963 , respectively $18 \mathrm{~mm}$ long $\times 16 \mathrm{~mm}$ wide and $16 \mathrm{~mm} \mathrm{long} \times 12 \mathrm{~mm}$ wide; branchial aperture terminal. The test is colourless, transparent, and carrying a small amount of mud on the smooth surface.

Transverse muscles on the right side of mantle body, branchial aperture 6lobed, short atrial siphon near the middle of body. The anterior margin of visceral mass around the level of the base of atrial siphon.

Transverse vessels 70 to 80 and internal longitudinal vessels about 30 on each side of branchial sac, 3 or 4 stigmata in a mesh, papillae large but intermediate ones absent, no plications formed. Tentacles about 30 excluding minute ones, ciliated groove a transverse slit in the larger specimen but crescent-shaped in the smaller, the edge of dorsal lamina smooth throughout in the smaller specimen but serrated in the anterior but nearly smooth in the posterior half in the larger. Three notodelphid copepods were included in the branchial sac of the smaller specimen.

The first and second intestinal loops are greatly bent dorsads, the axis of the second loop passes across the intestine far behind the pyloric end of the stomach which is elongate and marked with indistinct plications. The distal portion of the rectum proceeds anteriorly to the anus with the plain margin. Gonads immature,

Remarks: The present specimens differ from the type of the species in that the visceral mass is situated somewhat posteriorly. In the type, the mass is situated witk. 
its middle at the level of the base of the atrial siphon. As gamma itself is proposed provisionally, it is necessary to obtain perfect specimens of such a type before the conclusive discussions are made on this species. The intestinal loops strongly bent dorsads remind us of $A$. citrina Nishikawa and Tokioka, 1975. In $A$. citrina, however, the visceral mass is much smaller and the branchial sac extends far posteriorly beyond the margin of the mass.

\section{Corella japonica Herdman, 1880}

(Fig. 5, 34-36)

Corella japonica Tokioka and Nishikawa (1975): Publ. Seto Mar. Biol. Lab., 22 (5), pp. 332-334, figs. 22-23.

There are 10 specimens in the material collected at Ankyaba, 3-5 m deep, on May 8, 1961. Measurements, some structures and state of these specimens are given next.

\begin{tabular}{|c|c|c|c|c|c|c|c|}
\hline \multirow[b]{2}{*}{$\begin{array}{l}\text { Specimen } \\
\text { number }\end{array}$} & \multicolumn{2}{|c|}{ Size } & \multicolumn{4}{|c|}{ Number of } & \multirow[b]{2}{*}{ Gonad } \\
\hline & $\begin{array}{c}\text { length } \\
\mathrm{mm}\end{array}$ & $\begin{array}{c}\text { width } \\
\mathrm{mm}\end{array}$ & $\begin{array}{c}\text { longit } \\
\text { left }\end{array}$ & $\begin{array}{l}\text { vessels } \\
\text { right }\end{array}$ & $\begin{array}{c}\text { dorsal } \\
\text { languets }\end{array}$ & tentacles & \\
\hline 1 & 13 & 18 & 24 & 26 & 27 & 26 & mature \\
\hline 2 & 15 & 11 & 28 & 27 & 16 & 46 & mature \\
\hline 3 & 16 & 12 & (mantle & & & & \\
\hline 4 & 16 & 13 & 27 & 27 & 24 & 40 & spent \\
\hline 5 & 17 & 15 & 26 & 29 & 31 & 42 & mature \\
\hline 6 & 18 & 12 & 26 & 27 & 26 & 46 & mature \\
\hline 7 & 18 & 16 & 27 & 28 & 26 & 48 & mature \\
\hline 8 & 19 & 14 & 26 & 29 & 25 & ca. 50 & mature \\
\hline 9 & 19 & 14 & 24 & 23 & 25 & 38 & mature \\
\hline 10 & 21 & 13 & 26 & 27 & 25 & ca. 50 & mature \\
\hline
\end{tabular}

The translucent test is gelatinous but somewhat hard enough in posterior parts to carry colonies of some didemnids on the surface, that is generally smooth, though may be wrinkled, except the no. 1 specimen which is furnished in the anterior half with fine hairy processes but in the posterior half with much thicker root-like processes.

Both siphons are generally terminal, but the atrial may be subterminal in some specimens; both apertures are 6-lobed, atrial lobes are generally bifid and some or all of branchial lobes may be similarly subdivided into a pair of lobules. Muscles of the mantle body are less developed in these specimens and found merely around both siphons. Especially, the no. 1 specimen is wholly devoid of any muscles on the right side, although two fragments are seen on the left side of the body. The visceral mass is relatively small, its anterior margin never reaching anteriorly beyond the middle of the body. 

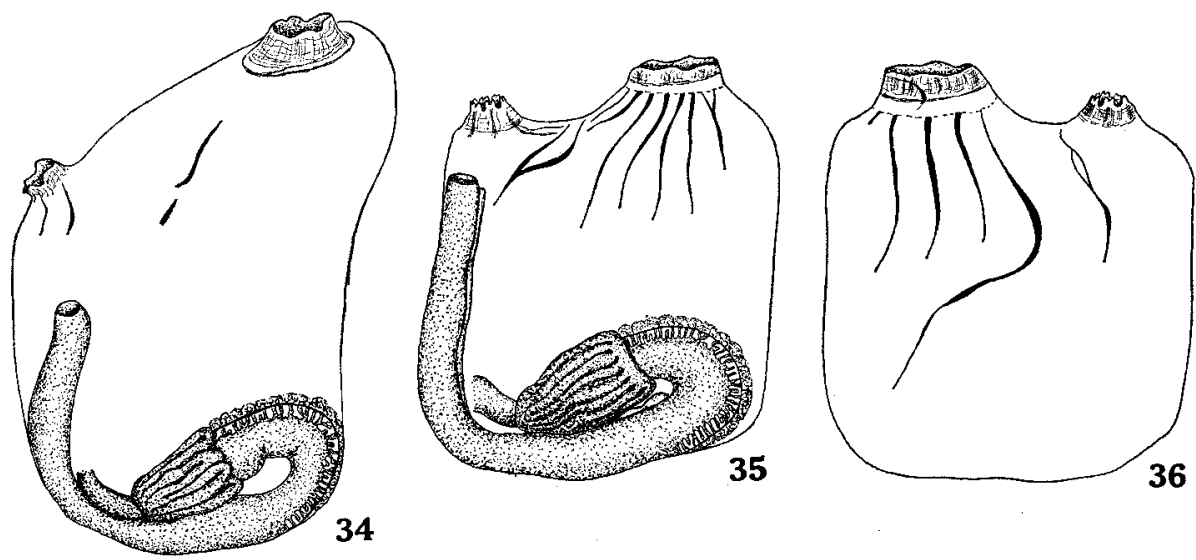

Fig. 5. 34-36: Corella japonica Herdman. 34-mantle body of $13 \mathrm{~mm}$ long $\times 8 \mathrm{~mm}$ wide specimen, right side. 35 - mantle body of $21 \mathrm{~mm}$ long $\times 13 \mathrm{~mm}$ wide specimen, right side. 36 - the same, left side.

Spirals are arranged in 23 to 25 transverse and up to 20 longitudinal rows on each side of the branchial sac. Larger and smaller tentacles alternating regularly. Ciliated groove a simple transverse slit, $\mathrm{C}$-shaped and open anteriorly, or an oval opening elongated transversely. Stomach globular and with about 15 plications. The ovary is extending over the left side of the intestinal loop, while testicular follicles are fringing the periphery of the loop. The vas deferens seems to have a spiral structure within the duct (?), as suggested by Matsumoto. About 50 gammarid amphipods of different sizes were found in the branchial sac and the peribranchial cavity of the no. 9 specimen.

Remarks: Most of the present specimens are closely related to those preveiously reported from Kabira of Isigaki Island (Tokioka and Nishikawa, 1975). The reduction of mantle musculature is regarded as a general trend in the specimens occurring in the warmer waters.

16. Botrylloides violaceus Oka, 1927

(Fig. 3, 23)

Four colonies collected at Simoiso, Ankyaba on May 30, 1961. They are respectively $3 \mathrm{~mm} \times 4 \mathrm{~mm}, 6 \mathrm{~mm} \times 9 \mathrm{~mm}, 9 \mathrm{~mm} \times 18 \mathrm{~mm}$, and $10 \mathrm{~mm} \times 23 \mathrm{~mm}$ in extent and $2 \mathrm{~mm}$ in thickness. The $6 \mathrm{~mm} \times 9 \mathrm{~mm}$ colony contains a few larger zooids and a number of smaller zooids newly built by budding. The former are up to $3.1 \mathrm{~mm}$ in length, purplish brown and with an irregular dark pigmentation, laid parallel to the colony surface, and opening directly to the exterior by both apertures (Fig. 3, 23). The latter are up to $1.2 \mathrm{~mm}$ in length, colourless and nearly transluscent, and wholly embedded inside the colony test without any communication with the exterior.

Zooids of two larger coloies are all contracted strongly to $1.2 \mathrm{~mm}$ or a little more 
in length. They are purplish brown throughout the body, though the anterior surface of the atrial languet is coloured orange brown, and provided with 9 stigmatal rows on the right side; the 2 nd row never reaching the mid-dorsal line. The intestinal loop covers posterior 3 or 4 stigmatal rows, the stomach is furnished with 9 plications excluding the typhlosolis and a pyloric coecum of the usual type and size. A large ovum dorsal to testis consisting of up to 15 follicles.

\section{Polycarpa cryptocarpa (Sluiter, 1885)}

(Fig. 6, 37-39)

Polycarpa cryptocarpa Tokioka (1967): U.S. Nat. Mus. Bull. 251, pp. 173-174, fig. 71. (1970): Publ. Seto Mar. Biol. Lab., 18 (2), pp. 95-97, fig. 7.

Three specimens collected at Ankyaba on May 8, 1961 and seven collected by Ohishi at Seso on July 8, 1963. The smallest specimen in the material is $17 \mathrm{~mm}$ long $\times 11 \mathrm{~mm}$ wide, while the largest is $40 \mathrm{~mm}$ long $\times 25 \mathrm{~mm}$ wide. Test leather$y$, pale to dark brownish and generally fouled on the surface with shell fragments or algae, sometimes burrowed by some bivalves; section and inner surface whitish.

The mantle body, inclusive of the branchial sac and visceral mass, is chocolate brown. Both apertures are 4-lobed on the mantle body. Numerous spherical capsules, about $100 \mu$ in diameter and brownish, nearly black, or quite transparent, are scattered all over the inner surface of the mantle.

Branchial folds strictly four on each side. Branchial formula as follows in two examined specimens.

$27 \mathrm{~mm}$ long specimen:

Left D. 2 (10) 2 (11) 3 (15) 2 (14) $3 \mathrm{~V}$.

Right D. 5 (10) 3 (14) 2 (14) 4 (11) 3 V.

$37 \mathrm{~mm}$ long specimen:

Left D. 2 (13) 4 (18) 4 (18) 4 (18) 4 V.

Right D. 0 (19) 4 (18) 5 (17) 5 (15) 4 V.

Eight to 12 stigmata in a mesh. Ciliated groove complicatedly cut into pieces in specimens from Ankyaba ( 30 to $37 \mathrm{~mm}$ long), but quite simple in those from Seso (17 to $40 \mathrm{~mm}$ ). Pyloric coecum definable in some specimens; 3 or sometimes 2 endocarps in first intestinal loop; second intestinal loop very deep, axis across the middle to the cardiac end of stomach.

Gonads completely embedded in mantle; nearly matured in specimens from Ankyaba, but wholly emptied in those from Seso.

In addition, a $27 \mathrm{~mm}$ long $\times 25 \mathrm{~mm}$ wide specimen was collected by Ohishi at Suriko on July 4, 1963. The alimentary canal is lost in this specimen. However, structures of the branchial sac and gonads completely buried in the mantle are quite the same as in the above-mentioned individuals. The present species has been recorded already from the Japanese waters, but neither description nor figures being 


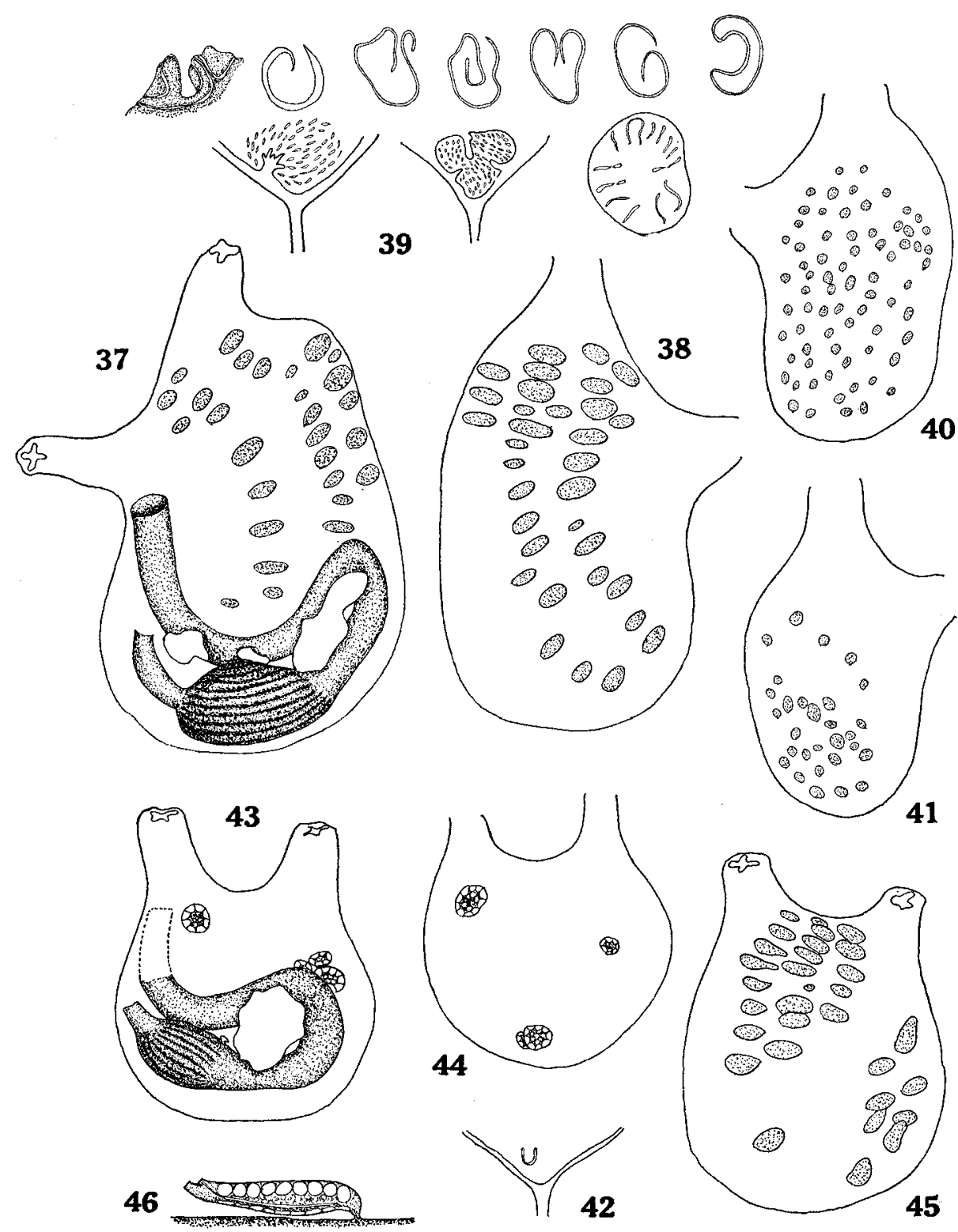

Fig. 6. 37-39: Polycarpa cryptocarpa (Sluiter). 37-mantle body of $37 \mathrm{~mm}$ long $\times 32 \mathrm{~mm}$ wide specimen from Ankyaba, left inner side. 38-the same, right inner side. 39-above: ciliated grooves of 17 to $40 \mathrm{~mm}$ long specimens from Seso, and below: those of 30 to $37 \mathrm{~mm}$ long specimens from Ankyaba. 40-44: Polycarpa iwayamae Tokioka. 40-mantle body of specimen from Ankyaba, left inner side. 41-the same, right inner side. 42-the same, ciliated groove. 43-mantle body of specimen from Seso, left inner side. 44-the same, right inner side. 45-46: Polycarpa maculata (Hartmeyer). 45-mantle body, right inner side. 46optical section of gonad. 
given. On the other hand, general occurrences of the variety of the species, var. kroboja Oka, have been confirmed in Japan. Therefore, this is an important chance to confirm actually the occurrence of the typical form of $P$. cryptocarpa in Japan. The absence of an excess rudimentary branchial fold on the right side and complicated configuration of the ciliated groove are regarded as the characteristics for typical cryptocarpa.

\section{Polycarpa iwayamae Tokioka, 1950}

(Fig. 6, 40-44)

Polycarpa iwayamae Tokioka (1967): U.S. Nat. Mus. Bull. 251, pp. 174-176, fig. 72. (1970): Publ. Seto Mar. Biol. Lab., 18 (2), pp. 97-99, fig. 8.

Two mature specimens in the material, a $24 \mathrm{~mm}$ long $\times 20 \mathrm{~mm}$ wide individual collected at Ankyana on May 8, 1961 and a $17 \mathrm{~mm}$ long $\times 18 \mathrm{~mm}$ wide individual collected by Ohishi at Seso. The larger specimen bears posteriorly a $17 \mathrm{~mm}$ long test extension and the whole alimentary canal is lost, while the smaller one has an incision by scissors for research of parasitic copepods and thus the ciliated groove and the distal half of the alimentary canal are missing. Test leathery, grayish white, and the surface irregularly wrinkled. Both apertures terminal, nearly sessile, and surrounded by many small prominences. Mantle pale brown, branchial sac with a tint of orange.

Internal longitudinal vessels are arranged as follows:

$17 \mathrm{~mm}$ long specimen:

Left D. 2 (10) 2 (12) 2 (13) 3 (10) 2 V.

Right D. 2 (12) 3 (12) 3 (13) 3 (14) 2 V.

$24 \mathrm{~mm}$ long specimen:

Left $\quad$ D. 0 (14) 2 (13) 3 (10) 3 (11) 2 V.

Right D. 2 (8) 2 (13) 3 (12) 3 (11) 3 V.

Transverse vessels arranged as---13231--- in the order of thickness, parastigmatic vessels present in some parts, 6 to 8 stigmata in a mesh. Tentacles about 10 in the smaller specimen, but 26 inclusive of minute ones in the larger specimen, and large and small or minute ones alternating. Giliated groove U-shaped in the larger specimen.

In the smaller specimen, the stomach occupies the proximal one-third of the ventral branch of the first intestinal loop and is furnished with about 20 plications on the surface and a pyloric coecum. A single large endocarp in the loop.

There are about 30 gonads in the ventral half on the left and about 80 all over the right side in the larger specimen, while only 9 on the left and 4 on the right side in the smaller. Gonads are all protruded out from the mantle surface. This feature, together with the simple ciliated groove and lighter colouration of the test and mantle, may be enough to justify the present identification. Much fewer gonads in the smaller specimen may be an unusual feature. 


\section{Polycarpa maculata Hartmeyer, 1906}

(Fig. 6, 45-46)

Polycarpa maculata Hartmeyer (1906): Zool. Anz., 31, pp. 17-18, fig. 10.

Tokioka (1953): Ascidians of Sagami Bay, pp. 250-251; pl. 51, figs. 1-7. (1959): Publ. Seto Mar. Biol. Lab., 7 (2), pp. 228-229; pl. 15, figs. 15-20.

A mature, $17 \mathrm{~mm}$ long $\times 17 \mathrm{~mm}$ wide specimen collected by Ohishi at Suriko on July 6, 1963 and preserved in alcohol. Apertures nearly sessile. Test leathery, grayish white, and the surface irregularly wrinkled and partly encrusted by some didemnids. A bivalve is found buried in the test near the atrial aperture. Mantle and branchial sac pale chocolate brown. Both apertures 4-lobed on mantle, siphons very short. Numerous shperical bodies, about $30 \mu$ in diameter, distributed densely on the inner surface of mantle.

No endocarps.

Branchial formula as follows.

Left $\quad$ D. $0 \quad$ (9) 3 (14) 3 (15) 3 (14) 3 V.

Right D. 0 (9) 3 (12) 3 (14) 3 (10) 3 V.

Two or 3 thinner transverse vessels between thicker ones, parastigmatic vessels absent, 6 or 7 stigmata in a mesh. Tentacles 40 excluding minute ones. Ciliated groove C-shaped, opened anteriorly and slightly sinuous. The alimentary canal is much mutilated. The stomach occupies the most part of the ventral branch of the first intestinal loop, is elongate and furnished with about 20 plications.

Elongated oval gonads all over respective sides, 23 on the left and 31 on the right side. They are up to $1.5 \mathrm{~mm}$ in length and attached to the mantle by a short string issued from the proximal end; exceptionally the string is issued from near the genital aperture in a gonad. About 20 testicular follicles are arranged irregularly or sometimes in two rows on the surface facing the mantle. Ovarian eggs are about $100 \mu$ in diameter. The wall of gonads contains numerous spherical bodies, about $10 \mu$ in diameter.

Remarks: The number, arrangement and attaching way of gonads, together with the branchial formula, in the present specimen are the main reasons for the identification with maculata. This species has been known from Tango (Hartmeyer 1906), $80 \mathrm{~m}$ deep, and Wakasa Bay (Tokioka 1959), by dredge, on the Japan Sea coast and from Sagami Bay (Tokioka 1953), 50 fathoms. The present locality, the shallow water near the subtropical sea, is rather striking in contrast with former localities.

\section{Cnemidocarpa fertilis (Hartmeyer, 1906)}

(Fig. 7, 47-49)

Styela fertilis Hartmeyer (1906): Zool. Anz., 31, p. 10.

Cnemidocarpa fertilis Tokioka (1953): Ascidians of Sagami Bay, pp. 256-259; pl. 55, figs. 1-10; pl. 56, figs. 1-9; pl. 57, figs. 1-10. (1967): U.S. Nat. Mus. Bull. 251, p. 183, fig. 77a. 
A $12 \mathrm{~mm}$ long $\times 13 \mathrm{~mm}$ wide specimen collected by Ohishi at Suriko on July 6, 1963, and preserved in alcohol. Test thin, leathery, pale yellowish, and the surface wrinkled. Both apertures situated close to each other, nearly sessile, and surrounded by irregularly scattered small prominences. Mantle pale orange, with many endocarps on the inner surface.

Internal longitudinal vessels arranged as follows.

Left D. 4 (20) 6 (17) 4 (17) 4 (11) 3 V.

Right D. 5 (22) 6 (20) 5 (24) 4 (14) 4 V.

Two or 3 thinner transverse vessels between thicker ones, parastigmatic vessels generally present, and 4 or 5 stigmata in a mesh. Tentacles 18, stout; ciliated groove as a longitudinal slit; dorsal lamina high and with the smooth edge.

Stomach elongate, occupying the most part of ventral branch of first intestinal loop, and furnished with about two dozens of plications on the surface and a pyloric coecum. Second intestinal loop wide and shallow, axis across the anterior part of oesophagus. Gonads 2 on the left and 5 on the right side; each with nearly emptied ovary, though some eggs left in some, and testicular follicles usually packed closely in double rows on the attachment surface.

Remarks: The large, elongate stomach in the present specimen reminds us of $C n$. macrogastra (Oka). However, it is known already that the stomach length is significantly variable in fertilis as in Styela partita previously noted by the present authors (1975). Moreover, the smooth body of macrogastra is generally much elongated, markedly compressed laterally, and attached to the substratum by whole left side.

\section{Pyura lignosa Michaelsen, 1908}

(Fig. 7, 50-52)

Pyura lignosa Michaelsen (1908): Mitth. Naturhist. Mus. Hamburg, 25, pp. 256-259; pl. 1, fig. 2; pl. 2, figs. 20-21.

Van Name (1945): Bull. American Mus. Nat. Hist., 84, pp. 336-338, fig. 222.

Tokioka (1972): Publ. Seto Mar. Biol. Lab., 19 (6), pp. 403-408; fig. 9, 51-94; fig. 10, 65-70.

aff. lignosa Tokioka (1970): Seto Mar. Biol. Lab., 18 (2), pp. 103-106, fig. 11.

An elongate, $16 \mathrm{~mm} \times 11 \mathrm{~mm}$ wide specimen collected by Ohishi at Seso on July 8, 1963. The animal bears posteriorly a $9 \mathrm{~mm}$ long test extension and is attached to the substratum by posterior, left ventral side of the body. The test surface is covered wholly with small scaly areas of various sizes, up to $0.7 \mathrm{~mm}$ in diameter and white, pinkish or red in colouration. The total body is thus coloured pinkish, especially on the ventral side and attachment surface. The branchial siphon is terminal and the atrial at the middle of the body proper, the former is surrounded by small protuberances instead of scaly areas. The area surrounding respective siphons is coloured deep red, and the distal end of siphons and distal part of the inner surface of siphons are densely dotted with small bluish white spots. The inner surface of siphons are furnished with many small flat epithelial projections, 

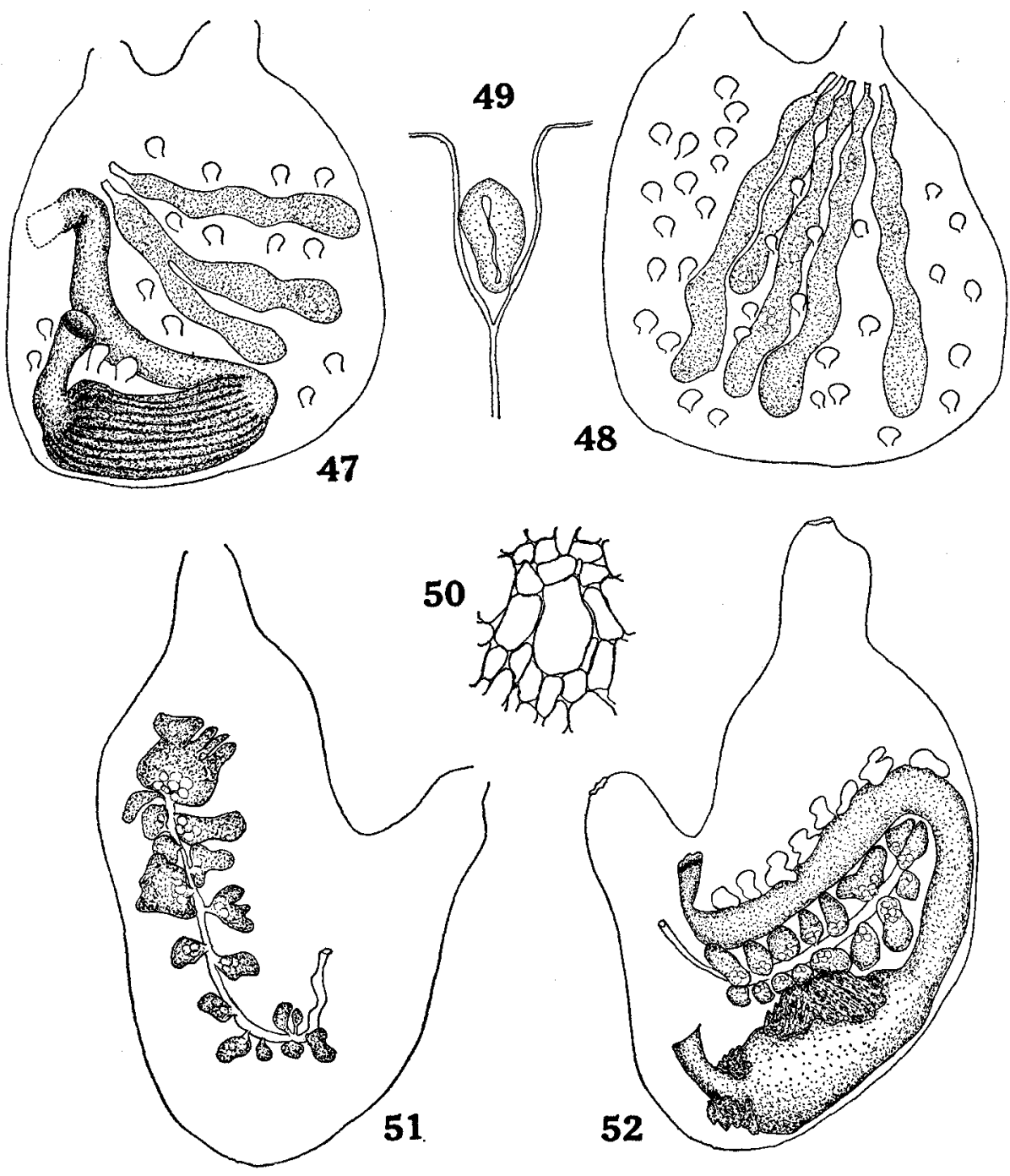

Fig. 7. 47-49: Cnemidocarpa fertilis (Hartmeyer). 47-mantle body, left inner side. 48-the same, right inner side. 49-ciliated groove. 50-52: Pyura lignosa Michaelsen. 50-a part of test surface. 51 -mantle body, left inner side. 52-the same, right inner side.

transversely elongate, but no spinules can be found there.

The mantle is orange, the branchial siphon of the mantle body is $4 \mathrm{~mm}$ in length and with the aperture 4-lobed; the atrial siphon is $3 \mathrm{~mm}$ long and with the aperture 8-lobed.

Seven folds on each side of branchial sac, the ventral-most one on the left side limited to the anterior half. Internal longitudinal vessels arranged as follows.

Left $\quad$ D. 0 (10) 2 (10) 3 (13) 3 (13) 4 (10) 3 (9) 6 (4) 0 V.

Right D. 0 (10?) 3 (8) 3 (15) 4 (14) 4 (12) 3 (11) 3 (2) 0 V. 
Parastigmatic vessels present, 5 or 6 stigmata in a mesh. Tentacles very fine, about a dozen exclusive of minute ones; branches of the 2nd order sparse, dorsal languets fine.

The anterior end of the alimentary canal reaches the middle of the distance between both siphons. The second intestinal loop is shallow, with other part of gut, anal margin undulating irregularly. Liver consisting of cardiac and pyloric masses, the former divided into dorsal and ventral lobes fringing respective sides of the cardiac portion, while the latter occupying the dorsal side near the pyloric end of gastric region. A relatively large prominence is protruded out from the inner pyloric corner, but being covered by a genital capsule. About 10 endocarps along the periphery of dorsal branch of first intestinal loop, coloured orange; no other endocarps.

The left gonad in the first intestinal loop consists of 16 genital capsules, while the right one of 17 capsules. Capsules orange as a whole, eggs dark yellowish and testicular follicles whitish.

Remarks: The present specimen is related most closely to sp. aff. lignosa from the Philippines, but differs from all those previously described in having 7 branchial folds in place of 6 in the latter, although it seems unlikely that this differ ence is taxonomically very significant. Missing of spinules on the inner surface of siphons in the present specimen might be due to unskillful handling at observation.

\section{Herdmania momus (Savigny, 1816)}

A $23 \mathrm{~mm}$ long $\times 27 \mathrm{~mm}$ wide specimen collected by Ohishi at Honohosi on July 11 and two specimens, $24 \mathrm{~mm}$ long $\times 26 \mathrm{~mm}$ wide and $21 \mathrm{~mm}$ long $\times 27 \mathrm{~mm}$ wide respectively, collected by Ohishi at Seso on July 8, 1963. The specimen from Honohosi with 9 branchial folds on the left and 8 on the right side, while the $21 \mathrm{~mm}$ long $\times 27 \mathrm{~mm}$ wide specimen from Seso with 8 on each side, ventral-most folds limited to the anterior part of sac.

\section{Microcosmus propinquus Herdman, 1882}

Microcosmus propinquus Herdman (1882): Challenger Rep., 6, pp. 132-133; pl. 14, figs. 5-6. Sluiter (1904): Siboga Exped., Monogr. 56a, p. 51.

Tokioka (1952): Publ. Seto Mar. Biol. Lab., 2 (2), pp. 128-130, fig. 24.

A $18 \mathrm{~mm}$ long $\times 19 \mathrm{~mm}$ wide specimen collected by Ohishi at Seso on July 8,1963 . The animal is roughly round, attached to the substratum by the posteroventral part of the body, and with the branchial siphon at the anterior end and the atrial at the middle; both apertures are 4-lobed. Test leathery, thin, almost smooth on the surface, and whitish but faintly orange around both siphons; an empty burrow probably by a bivalve near branchial apertrue. Inner surface of siphons armed with spinules, about $10 \mu$ in length.

The mantle is very thin, nearly translucent and yellowish, but it is thickened 
and coloured orange yellow on siphons. The musculature is very regular, consisting of longitudinal muscles converging to the branchial siphon and transverse ones diverging from the atrial.

Branchial folds 7 on each side, 7th (ventral-most) limited to the anterior part of sac. Internal longitudinal vessels are arranged as follows.

$$
\begin{aligned}
& \text { Left D. } 3 \text { (18) } 2 \text { (14) } 2 \text { (18) } 2 \text { (15) } 3 \text { (16) } 2 \text { (12) } 2 \text { (6) } 0 \text { V. } \\
& \text { Right D. } 1 \text { (15) } 2 \text { (14) } 2 \text { (16) } 3 \text { (16) } 2 \text { (15) } 3 \text { (13) } 3 \text { (11) } 1 \text { V. }
\end{aligned}
$$

Transverse vessels arranged as ---132323231--- or ---13232323231---in the order of thickness, parastigmatic vessels present, and about 8 stigmata in a mesh in interspaces between folds. Prebranchial area papillated; tentacles 13 exclusive of minute ones, larger and smaller ones alternating, branches in 2 orders; ciliated groove G-shaped, opened anteriorly and with both horns incurled; dorsal lamina high and with the smooth edge.

Second intestinal loop very shallow, axis across the pyloric end of gastric region; anal margin plain. Gonads fully matured, each divided into several lobes; faintly pinkish testicular follicles on the exposed side and reddish brown eggs on the attachment side of gonad.

Remarks: The present specimen resembles some of the described specimens of $M$. exasperatus Heller, for instance the specimen from Port Jackson described by Tokioka (1967; fig. 96, h, i on p. 214). However, M. exasperatus has generally 8 to 10 branchial plications, though rarely 7 in very small specimens $(8 \mathrm{~mm}$ long specimen from Saipan Island, Tokioka 1967, p. 213). There are five species of Microcosmus in the western Pacific, which are provided with 7 branchial folds on each side. Of these, polymorphus Heller and hartmeyeri Oka are distinguishable from others by their larger body size and much thicker mantle. M. multitentaculata Tokioka is seemingly unique in the shape of the gonad and haemisphaerium Sluiter is separable from the present specimen by having the larger gastric region. Then, the last species propinquus seems to be related most closely to the specimen here described. The number of stigmata in a mesh in the specimen conforms to that given by Sluiter (1904, 8 or 9 in a mesh). However, Herdman (1882) gave about 12 and Tokioka (1952) only 3 . The number may vary considerably with the size of specimens and also according to the parts of the branchial sac.

\section{REFERENCES}

Hartmeyer, R. 1906. Ein Beitrag zur Kenntnis der japanischen Ascidienfauna. Zool. Anz., vol. 31, pp. $1-30,12$ text-figs.

Hastings, A.B. 1931. Tunicata. Great Barrier Reef Exp., Sci. Rep., vol. 4, no. 3, pp. 69-110, 17 text-figs., pls. 1-3.

Herdman, W.A. 1882. Reports on the Tunicata I. Ascidiae Simplices. Rep. Challenger Exped., Zool., vol. 6 , pt. 17,296 pp. 37 pls.

1899. Descriptive catalogue of the Tunicata in the Australian Museum, Sydney, N.S.W., Liverpool, 139 pp., 45 pls.

Nishikawa, T., \& Tokioka, T. 1975. Contributions to Japanese ascidian fauna XXVI. Notes on simpie ascidians commonly found in the waters near the Sabiura Marine Park Research Laboratory. Publ. Seto Mar. Biol, Lab., vol. 22, nos. 1-4, pp. 217-222, 2 text-figs. 
Sluiter, G. Ph. 1904. Die Tunicaten der Siboga-Expedition, pt. 1. Die sozialen und holosomen Ascidien. Siboga-Exped., Monogr. 56a, 126pp., 15 pls.

1909. Ibid., pt.2. Die merosomen Ascidien. Ibid., 56b, 112 pp., 2 text-figs., 8 pls.

Tokioka, T. 1950. Ascidians from the Palao Islands I. Publ. Seto Mar. Biol. Lab., vol. 1, no. 3, pp. 115-150, 23 text-figs.

1953a. Ascidians of the Sagami Bay. Tokyo, 315 pp., 25 text-figs., 80 pls.

1953b. Controbutions to Japanese ascidian fauna V. Ascidians collected near the Marine Biological Laboratory of Hiroshima Univercity in the Inland Sea (1). Publ. Seto Mar. Biol. Lab., vol. 3, no. 1, pp. 1-25, 16 text-figs.

1953c. Contributions to Japaneses Ascidian fauna VI. Simple ascidians of the Museum of Hukui. Ibid., vol. 3. no. 1, pp. 27-32, 3 text-figs., 1 pl.

1954. Contributions to Japanese Ascidian fauna VII. Invertevrate fauna of the intertidal zone of the Tokara Islands. VII. Ascidians. Ibid., vol. 3, no. 3, pp. 239-264, 2 text-figs., pls. 18-37.

1959. Contributions to Japanese Ascidian fauna XIII. Sporadic memoranda (4). Ibid., vol. 7, 2, pp. 223-236, 1 text-figs., pls. 13-18.

1963. Contributions to Japanese Ascidian fauna XX. The outline of Japanese Ascidian fauna as compared with that of the Pacific coasts of North America. Ibid., vol. 11, no. 1, pp. $131-156$.

1967a. On a small collection of ascidians from the vicinity of Nhatrang, Viet Nam. Ibid., vol. 14, no. 5, pp. 391-402, 5 tex-figs.

1967b. Pacific Tunicata of the United States National Museum. U.S. Nat. Mus. Bull. 251, 247 pp., 105 text-figs.

1970. Ascidians from Mindoro Island, the Philippines. Publ. Seto Mar. Biol. Lab., vol. 18, no. 2, pp. 75-107, 12 text-figs.

1972. On a small collection of ascidians from the Pacific coast of Costa Rica. Ibid., vol. 19 , no. 6 , pp. 383-408, 10 text-figs.

Tokioka, T., \& Nishikawa, T. 1975. Contributions to Japanese Ascidian fauna XXVII. Some ascidians from Okinawa, with notes on a small collection from Hong Kong. Ibid., vol. 22, no. 5, pp. 323-341, 40 Text-figs.

Van Name, W.G. 1918. Ascidians from the Philippine and adjascent waters. U.S. Nat. Mus. Bull., 100 , vol. 1, pt. 2, pp. 49-111, 115 text-figs., pls. 22-33.

1945. The North and South American Ascidians. Bull. American Mus. Nat. Hist., vol. 84, 476 pp., 327 text-figs, pls. 1-31. 